\title{
Strategy of Managing Sunday Morning Market in Gadjah Mada University and its Effect on Sellers' Income
}

\author{
${ }^{1}$ AZIS MUSLIM, ${ }^{2}$ ARINA BARIROH \\ 1,2 Dakwah and Communication of Yogyakarta Sunan Kalijaga State Islamic University \\ email: ${ }^{1}$ muslimtenan@gmail.com; ${ }^{2}$ arinabariroh63@gmail.com
}

\begin{abstract}
Sunday Morning market can be the driver of community's economic growth. This market can encourage the development of small and medium scale enterprises. Nevertheless, this market existence is often considered as harmful to environment as it is usually established on the street edge and causes a traffic jam. It is reasonable that this market is vulnerable to eviction. Therefore, this market needs well-management in order to stay and avoid eviction. This research aimed to explore Sunday Morning market managing strategy in Gadjah Mada University conducted by market organizer and its effect on sellers' income. This research was conducted using qualitative approach. The result of research showed that before specifying the strategy to be taken in market management, the management should first do observation on market environment by analyzing strength, weakness, opportunity, and threat. Considering the result of analysis, nine strategies were determined to manage Sunday Morning market. The nine strategies specified, in fact, exerted different effect on sellers' income: some of them could increase income, some could not, and some had no effect at all.
\end{abstract}

Keywords: Market, Management Strategy, Sellers' Income.

\section{Introduction}

The rapid development of Indonesian economy currently can be measured by the prevalent development of trade centers. The existence of trade centers is one of most real indicators concerning the community's economic activity in a region (Ayuningsasi, 2011). Viewed from economic interest, the increasing number of trade centers can encourage the creation of job opportunity from business performers, security unit personnel service, shopkeeper, product deliverer, cleaning service, and transportation service. It means that the presence of trade center contributes to the dealing with unemployment and poverty problems.

On the other hand, the less strong fundamental of Indonesian economy today encourages government and private to keep empowering small and medium scale enterprises (SMEs). It is because this sector has been evidently able to absorb workers and survive from economic crisis exposure. This sector needs to be empowered continuously recalling that SME performers have many problems to deal with and to solve. Those problems involve limited work capital, marketing, low human resource quality, limited mastery of science and technology (Kristiyanti, 2012; Kurniawan \& Yun, 2018; Sudaryanto, Ragimun, \& Wijayanti, 2013).

The result of research on the cooperation between Cooperatives and Small and Medium Scale Enterprises Ministry and Central Statistic Agency in 2003 informs that $72.47 \%$ of SMEs encounter problem, while the rest of $27.53 \%$ does not encounter problem. The problems faced by SMEs are capital restriction of $51.09 \%$, marketing of $34.72 \%$, basic material of $8.59 \%$, manpower of $1.09 \%$, transportation of $0.22 \%$, and other problems of $3.93 \%$ (Winarni, 2006).

Capitalization indeed becomes main problem when business performers are running their business. However, another equally important problem is marketing. Marketing is a way of introducing a business' product to public, thereby they are interested in buying it. Through the sold product, their business will continue to exist and running. This statement is confirmed by Fitriyani (2017) saying that nearly $80 \%$ of small business

Received: June 29, 2018, Revision: July 30, 2018, Accepted: December 10, 2018

Print ISSN: 0215-8175; Online ISSN: 2303-2499. DOI: http://dx.doi.org/10.29313/mimbar.v34i2.3828.445-453

Accredited B based on the decree No.040/P/2014, valid on February, 18, 2014 until February, 18, 2019. Indexed by DOAJ, Sinta, IPI 
performers encountered failure in the first 5 years of their businesses due to marketing problem. Therefore, they require facilitation in marketing sector to make their products sold out in marketplace. The facilitation can be in the form of providing marketing location, promoting business' product, providing training on marketing, and etc.

In Gadjah Mada University (UGM) campus, there is a market that has been established for twenty years and becomes a media of marketing the small employers' products. The market is called Sunday Morning Universitas Gadjah Mada or Sunmor UGM. As suggested by its name, this market operates on Sunday morning only. In addition to be a place for marketing small employers' product, Sunmor UGM also becomes an icon of traditional market tour in Yogyakarta that is always crowded with tourists coming from inside and outside Yogyakarta City. For that reason, every Sunday morning, Sunmor UGM is always crowded with hundreds of sellers and thousands visitors.

The existence of Sunmor UGM with hundreds sellers and thousands visitors is surely inseparable from the role of association (Indonesian: paguyuban) managing it. Originally, there are four paguyubans managing Sunmor UGM: Paguyuban Sinar Pagi, Paguyuban Notonegoro, Paguyuban Fajar Wiradigama, and Paguyuban Pedagang Taman Kupu-Kupu. With so many paguyubans managing Sunmor UGM, in reality, do not make it tidier. Sunmor UGM becomes nonconducive to both sellers and visitors. Many problems result from street congestion in all directions toward Sunmor UGM: disorganized parking lot, accumulated rubbish due to market activity, visitors becoming pickpocket victims, and UGM campus' policy prohibiting the operation of Sunmor, as well as other problems. Considering so many problems arising and the difficulty to solve the problems, eventually the four paguyubans unite into one paguyuban (association) named Perkumpulan Pedagang Sunday Morning or PPSM (English: Sunday Morning Sellers Association). Its members consist of sellers and activist caring about Sunmor UGM market.

PPSM has a good strategy in managing Sunmor UGM. It can be seen from Sunmor UGM existency which getting crowded by both sellers and visitors and still running for almost 20 years. In addition, sellers feel positive effect of the chosen strategy implementation. It is interesting to study more in-depth on the strategy taken by PPSM in managing Sunmor
UGM. The objective is to give information that helps other market organizers in dealing with their problems. Therefore, this study focuses on PPSM's strategy in managing market and its effect on sellers' income.

Market, according to Simamora (2011) is a physical place in which buyers and sellers assemble to exchange products and services. Meanwhile, according to Belshaw (1981) market is a place in which a process of interaction between buyers' demand and sellers' supply (offering) over a product/ service occurs so that price can be defined corresponding to the volume of product or service traded.

Market, by the time when sellers and buyers meet, is divided into three categories: pasar kaget (incidental market/ Sunday market), daily market, and weekly market (Binsar, 2017). Pasar kaget is a market operating for a moment, only exist when there is a crowd or celebration. For example, in a fair or market operating during celebration events in local area. Meanwhile, daily market is the one operating every day, for example, traditional market and modern market where buyers can come everyday to shop. Meanwhile, weekly market is the one operating once a week and Sunmor UGM belongs to this market category.

Whatever the type, those markets need a reliable organizer to run well. The unmanaged market will run disorderly and ended up facing many problems. Otherwise, the market managed with appropriate strategy will generate much profit (Widyasari \& Yuniningsih, 2016). Market association is a means considered capable of managing market well. This association, according to Loso (2010), serves as a communication medium between sellers in the market, as the facilitator of sellers' interest, and as a connector between government and certain parties. Furthermore, Loso (2010) explains that market association can build a strategy to keep the market's existence.

Hunger \& Wheelen (2003) state that building strategy should start with observation on environment. Observation on environment is conducted by considering internal and external factors. Internal factor includes strength and weakness, while external one includes opportunity and threat. Siagian (1995) confirms that the organizers of strategy utilizing those two factors should maximize the role of strength and opportunity, minimize the weakness, and suppress the arising threat 
that should be deal with. If the strategy organizers can do those appropriately, the attempt of choosing and determining effective strategy will be usually fruitful.

\section{Research Method}

This research was conducted using qualitative approach since it can be the source of description and explanation entrenching more into the processes occurring in local context. In addition, this approach can build a closer relationship with informants as the target of this study. The approach could give the author an opportunity to reveal the chronology of social incidences, as well as and explaining causal relationship occurring in local event (Muslim, 2014).

This research took place at Sunmor UGM market which located in Notonegoro and East Ring Roads or called UGM's valley. The main informants were market organizer and sellers, while supporting informants were market visitors. Informants were selected using criterion technique. The criteria are daily market organizers, sellers who are actively involved in solving market problems, sellers who get advantage and disadvantage by market management policies, and visitors who shop frequently. Data was collected using observation, interview, and documentation. Data validation was conducted through persistent observation and triangulation. The technique of data analyzing used was interactive model analysis (Miles \& Huberman, 1984).

\section{A Glance of Sunmor UGM market}

Sunmor UGM market operates once a week from 06.00 a.m. to 12.00 p.m. This market establishment is inseparable from UGM's caring for Yogyakarta people's economic post-monetary crisis condition in 1998. Economic difficulty made some sellers, particularly those of college students, to take initiative to establish business around UGM Boulevard. They saw a good business chance, particularly culinary, because every Sunday UGM Boulevard area is repleted with people who do exercise. They believe that after exercising, those people will take a rest and buy some food for breakfast.

The term Sunmor UGM came from sellers' trading habit on Sunday morning only. It is in line with Ricky' statement as the operating coordinator of Sunmor:

"Originally, it was a form of UGM's concern to help sellers' difficulties during economic crisis. Boulevard area is allowed to be used for selling activity, as long as it does not harm academic activity.... Considering so many people doing exercise activity on Sunday morning before Graha Sabha Pramana building, the students began to operate business mostly in food and beverage areas. As time progresses, number of seller increases, so that many people call it Sunmor market".

Having the same opinion, Ponimin as the chairperson of market management stated that:

"This market was originally located in front of Graha Sabha Pramana in 1997 or 1998. At that time, many food and beverage sellers sold their products. Because buyers (those who do exercises) has increased in number, it was then moved to Notonegoro to Olahraga Roads, where the number of sellers also increased continuously".

As time progress, considering the large opportunity of getting business profit in this location, number of sellers increases continuously over weeks. In addition, the types of product sold are getting more varied. They include not only food and beverage products but also fashion, house appliance, and etc. This condition leads UGM to intervene in organizing the sellers to keep it conducive and not harming the academic activity process. It becomes the starting point of agreement between UGM and organizer of Sunmor market.

Cooperation agreement between UGM and market organizer includes, among others, market arrangement. Market should be rearranged to organize the sellers' orderliness and to maintain environment cleanliness. Therefore, Sunmor market location is moved to Notonegoro and Olahraga roads. This new location is accompanied with re-registration of sellers trading in Boulevard area. The rules are developed to maintain market sustainability. The rules aforementioned are 1) sellers who will trade on Notonegoro road are those who have traded in Boulevard area, 2) trading location should be included in cooperation agreement with UGM, 3) paying land lease cost specified according to land width, 4) prohibition of harming UGM's environment.

The bonding cooperation established between UGM and Sunmor market organizer was effective until the agreement ended in September 27, 2013. As the agreement ended, some new problems arose. UGM, through Directorate of Asset Management and 
Maintenance considers that the presence of Sunmor market is no longer relevant to the vision of campus planning. For that reason, Sunmor market should be moved to an area outside UGM, to East Ring Road for exact. On the other hand, the sellers declined the relocation plan delivered by UGM for some reasons. Since then, Sunmor market condition is no longer conducive. Sellers and Sunmor defending activists often negotiated and protested against UGM requiring the cancellation of relocation.

In early 2017, UGM and Sunmor market organizer agreed that the location of Sunmor in Notonegoro Streets will not be moved, but the sellers in Olahraga Street should be relocated. On the other hand, UGM allowed the use of East Ring Road to be a new location of market and appointed Sunday Morning Seller Association (PPSM) to manage the market.

PPSM is an association (paguyuban) accommodating four market organizing associations that have managed Sunmor market before: Paguyuban Wiradigama, Paguyuban Sinar Pagi, Paguyuban Notonegoro, and Paguyuban Pedagang Taman Kupukupu. The first paguyuban established was paguyuban Waradigama in 1998 with the aim to maintain partnership and communality among warung lesehan sellers and to build their positive image that they were not illegal business but the organized ones. Second one was paguyuban Notonegoro in 2002. It aimed to coordinate the sellers formerly trading at Boulevard and then moved to Notonegoro Street. The third was Paguyuban Sinar Pagi which established in 2008. It aimed to be a means of coordinating for sellers in expressing aspiration to UGM. The last one was Paguyuban Taman Kupu-Kupu established in 2009 with the aim to organize new sellers who want to trade in Sunmor market. These four paguyubans have different interests yet approved to unite into one paguyuban to negotiate with UGM in solving relocation problem.

\section{The strategy of Managing Sunmor UGM Market}

PPSM's attempt to determine Sunmor market managing strategy seems to be in line with Hunger and Wheelen's (2003) theory aforementioned. It is because before choosing and determining a strategy, PPSM first conducts an observation on environment by analyzing strength, weakness, opportunity, and threat existing in Sunmor market. The result of findings are obtained and explained below.

\section{Strength}

Firstly, the strategic location. The location of Sunmor market is very strategic, lying on Notonegoro Street and UGM East Ring Road. The two streets are located between two state universities: Universitas Gadjah Mada and Universitas Negeri Yogyakarta. Visitors can come to Sunmor market by both public transportation and private vehicle. In addition, Sunmor market's location is adjacent to UGM's Wisdom Park, a public space often used by public and UGM's civitas academics to do exercise or just enjoying its beautiful scenery. For that reasons, many visitors take a rest in this place after they run or walked around Sunmor while enjoying snacks they have bought.

Secondly, Sunmor UGM market has been well-known for quite a long time. It has been established since $90 \mathrm{~s}$. This market is more popular among the people compared to other markets. For example, when someone says Sunmor without naming the place, he/ she will think of Sunmor UGM, except if it is followed with other name such as Sunmor Prambanan, Sunmor Bantul, and etc.

Thirdly, it has many sellers. About 800 sellers vend their products in Sunmor market. Some sellers have membership card (permanent sellers) and some others do not have (incidental sellers).

Fourthly, the market sells complete products with cheap prices. Sunmor market provides many merchandise including house appliances, food, fashion, cosmetics, and etc. These various and complete products choices make the visitors stay longer in the market and look for products they want. In addition, the products traded are low-cost and affordable.

\section{Weakness}

Firstly, the parking lot is limited. Inadequate parking lot causes a traffic jam on the street of market area and make it seems disorganized. The streets are congested due to vehicles coming into and exiting from the same lane. The narrow area cannot provide specific parking lot for four-wheel vehicles. 
Secondly, a narrow trading location. In contrast to sellers in traditional market who have permanent building or kiosk, the sellers in Sunmor market, despite occupying the unchanged location every Sunday, sometimes being push aside by other sellers' shanties. It impacts on the narrowing space that should be utilized discretionarily by visitors to choose the products they want to buy. This space/street narrowing is due to the sellers expanding their shanties deceitfully by taking the adjacent sellers' area.

Thirdly, rubbishes/waste are scattered around. The visitors' low consciousness of clean and healthy environment leads them to littering. As a result, food and beverage packaging waste becomes dirty scenery which threat the beautiful arrangement of Sunmor market. The rubbishes and waste are scattered around on the sidewalk. Whereas, that sidewalk can be used by visitors to sit down and take a rest while enjoying some snacks.

\section{Opportunity}

Firstly: Sunmor market can become a medium for developing SMEs in Yogyakarta. It is proven by many sellers who survive and annually extend their contract period in Sunmor market which can be seen as an opportunity for the market organizer to make Sunmor market the media of developing SMEs for people in Yogyakarta. Koko, as treasurer and general administration of Sunmor market organizer says that sellers who registered as members of Sunmor market come from small and medium scale sellers. This statement is justified by Naima, a fashion seller who has online shop and joined Sunmor market last year. She says that trading in Sunmor market is a great help to market her products, particularly in promoting her products to public.

Secondly, Sunmor market as shopping and culinary tourist destination. Sunmor market is no longer considered as weekly market providing cheap products. Its presence has become a tourism icon for people in Yogyakarta. It can be seen from many visitors who are intentionally waiting and spending their time for shopping or merely looking for their favorite foods in Sunmor. They are willing to walk around Sunmor market for 2 $\mathrm{km}$ in length to choose and bargain products they want or merely browsing before buying the foods/products.

Thirdly, Sunmor market can compete with modern market. Sunmor market is a traditional market. However, this market can compete with modern market viewed from its number of visitors. It is as suggested by Ponimin that "thousands visitors come to Sunmor every Sunday. They would love to come because Sunmor provides a variety of products, either new or old (second-hand)".

\section{Threat}

Firstly, relocation. The probability of Sunmor relocation is very substantial. It is because Sunmor located in UGM campus area. If Sunmor market is considered harmful to UGM civitas academic's comfort, UGM will likely to relocate it. Tondy as the public relations officer of Sunmor market organizer said that relocation is still a threat to sellers, as relocation has ever happened to this market before from Olahraga Street to East Ring Road.

Secondly, it is susceptible to crime. The crowded visitors in Sunmor market can be easy targets for pickpockets. Because the space between sellers' shanties and road access for visitors is very narrow, the visitors jostle each other which make it easy for the pickpockets to do their crimes. This statement is justified by Fashiha, a victim of pickpocket, who says that "I often complain about the unguaranteed security. I have once lost my cellular phone. I put it in my bag, but when I wanted to pay the products, my bag had been perforated maybe with razor blade, and when I checked inside, my cellular phone had gone".

Thirdly, the decrease number of visitors which happened due to bad weather. For example, when it is rain, number of visitors visit this market decreases because it consists of tents only cover the sellers' products and can not be used as shelter for visitors. Therefore, visitors go and leave the market just the way they want. This statement is confirmed by Heni, an accessories seller, stating that "the market is quiet when it is rain. Hot weather does not matter, but when it is rain, number of visitors decreases.

Fourthly, similar market is located adjacently. After Sunmor market management dealt with PPSM, all sellers are obliged to register themselves to become official sellers organized by PPSM. However, the location of Sunmor in UGM East Ring Road is closer to residental area, so that many sellers vend their merchandise around the residence. Those who do not register as sellers under PPSM's management are considered illegal ones. As 
time progresses, the number of illegal sellers increases. Therefore, Karangmalang hamlet, in which these illegal sellers stay, initiates to organize them independently. It, of course, threats the existence of Sunmor UGM market management.

The result of observation on the environment above can be simplified into table 1.

Based on the result of observation on environment, PPSM chooses and determines the strategy of managing Sunmor UGM market as follows:

Firstly, regulation development. PPSM develops some regulations as guidelines for all market sellers and organizers. Those regulations include sellers' obligation to have member card, location leasing cost, environmental cleanliness, orderliness, and security retribution.

Secondly, the registration of incidental sellers. To accommodate the aspiration of people who want to trade incidentally, PPSM collects their data through registration. This registration is intended only for the sellers who do not have member cards. The registration is conducted every Saturday at PPSM Secretariat located on Jembatan Merah IV Street No.507, Condongcatur, Depok Sub District, Sleman Regency. One-time registration applies for one-time trading. It means that every seller with no member card obliged to register himself/herself every Sunday when they want to trade continuously.

Thirdly, promotion is conducted through social media. Social media is an option for PPSM to promote Sunmor market. It can be done by telling all sellers to take photo of their products and stalls, and then sending them to PPSM's account @sunmorugmjogja. Furthermore, PPSM will post them in its Instagram account and tag the sellers' Instagram account too. In this case, visitors can browse the products needed online and find the location easily.

Fourthly, providing personnel to keep the market clean. This strategy is taken to deal with litter scattered about the road. PPSM has actually told the visitors to dispose rubbish into trash can. However, many visitors look for the trash bin reluctantly and prefer to litter. Moreover, Sunmor market is a shopping and culinary tour destination; when the place is clean, it will attract more visitors. For that reason, the strategy of providing cleanliness personnel is the important strategy.

Fifthly, providing parking lot. The weaknesses found by PPSM are traffic congestion and disorganized motor vehicles in Sunmor market. To deal with the problem, PPSM choose strategy by providing parking lot to facilitate the visitors to access the road and to park their vehicle at the location intended.

Sixthly, negotiating with UGM. Sunmor market formerly located on Olahraga Street, which then relocated to Notonegoro Street by UGM because it disrupts access to the street. Such condition will likely to be repeated with the news circulating that Sunmor market on Notonegoro Street will be relocated to East Ring Road. It makes the sellers restless. For that reason, PPSM does a negotiation with UGM. The result is that Sunmor market may operate only along Notonegoro Street and East Ring Road. Meanwhile, the sellers vend on Olahraga Street should be relocated. It means that there is an expansion of market area.

Seventhly, cooperation with Bulaksumur Resort Police. Sunmor UGM market with the location adjacent to Sunmor Padukuhan Karangmalang market (managed by different management), affects negatively to the existence of both markets that may trigger, for example, friction between sellers. To anticipate that, PPSM establishes cooperation

Table 1

Observation on Environment based on SWOT Analysis

\begin{tabular}{|c|c|}
\hline Strength (S) & Weakness (W) \\
\hline $\begin{array}{l}\text { 1. Strategic Location } \\
\text { 2. Known by the public } \\
\text { 3. Having many sellers } \\
\text { 4. Complete and cheap product }\end{array}$ & $\begin{array}{l}\text { 1. Narrow location } \\
\text { 2. Inadequate parking lot } \\
\text { 3. Scattered-around rubbish/waste }\end{array}$ \\
\hline Opportunity (0) & Threat (T) \\
\hline $\begin{array}{l}\text { 1. As a medium of developing SMEs } \\
\text { 2. Becoming a tourist destination } \\
\text { 3. Competitive with modern market }\end{array}$ & $\begin{array}{l}\text { 1. Relocation } \\
\text { 2. Susceptibility to crime } \\
\text { 3. Decreased visitor number } \\
\text { 4. The presence of market organized by citizens }\end{array}$ \\
\hline
\end{tabular}


with Bulaksumur Resort Police to improve security and prevent the potential crime with the aim to provide security and comfortable condition for the visitors.

Eighth, establishing legal-entity organization. Sunmor market established on the street is very susceptible to eviction or relocation. It encourages PPSM to make Sunmor market a legal entity in order to have strong status and position. Currently, PPSM has been a legal-entity organization through a notary deed Number AHU-019-AH.02.01 dated on October 27, 2016 approved by Republic of Indonesia's Law and Human Rights Minister.

Ninth, location arrangement. PPSM makes location arrangement after an agreement with UGM to occupy Notonegoro Street and East Ring Road. The arrangement of Sunmor market location includes trading location, parking lot, wastebasket/trash can, one-way lane policy, and etc. This arrangement, in addition to make the market tidier, is also to give the visitors comfortable feeling that keep them stay longer and shop more, and prevents the illegal sellers from vending their merchandise there.

\section{The effect of Market Managing Strategy on Sellers' Income}

The result of field observation on the effect of Sunmor market managing strategy on the sellers' income can be classified into three categories: increasing income, lowering income, and no affecting income.

The strategy that can increase sellers' income is to provide parking lot. The parking lot available in some places, in fact, can break up the visitor accumulation in one point. Visitors will of course walk from parking lot to the sellers' shanties. The sellers' shanties located near the parking lot will surely be crowded with visitors, whether they are just passing by, looking around, or buying the products. Otherwise, the location of shanties that far away from parking lot will be quiet. It, of course, will only benefits the sellers whose locations are near the parking lot. Therefore, the sellers will benefit from the availability of many parking lots. They admit that their shanties are more crowded and many buyers come to buy their products. It is as suggested by Reni who stated that "Now this market is crowded, unlike in the past when the parking lot was far. Now, there are a lot of people passing by, and many of them buy things too which increases our income."

The strategy of providing adequate parking lot for visitors is the appropriate one in Sunmor market organization. This statement is at least confirmed by Widyasari \& Yuniningsih (2016), who investigated the strategy of Bangsri market management. They found that a cause of less optimal management of Bangsri market is the unavailability of adequate parking lot.

In addition, promotion through social media also impacts on the increased income of sellers. Naima, for example, explains that many buyers ask fashion model and motif she sells by showing picture and location. They sometimes only says "Mom, is this product sold here?" while showing the picture. They have browsed but have not found the product. It indicates that the buyers who come are ready to buy the products promoted in social media.

Theoretically, promotion through social media has many advantages: sellers can expand the market at local, national, and international levels with efficient time and cost. The sellers having broad market coverage will sell their merchandise easily and finally their income will increase (Rosyad, 2011; Sudaryanto et al., 2013).

Meanwhile, the strategies impacting on the decreased income of sellers are registration of incidental sellers, negotiation with UGM, and location arrangement. The sellers who have member card say that the registration of incidental sellers only benefits the market organizer. It is because those sellers give financial contribution every Sunday to the organizer as the location leasing fee. Meanwhile, those incidental sellers are the competitors for legal sellers (who have member card) that vending the similar products. They sometimes sell products at lower price to attract customers. They can also "likely" to get more strategic location. This price and location competition, according to the sellers with member card, can be disadvantageous and lowering their income. Meanwhile, according to market organizer, incidental sellers should be given place in order to be organized easily.

The result of negotiation with UGM, on the one hand, benefits both sellers and organizer, but on the other hand harms the sellers. To the sellers, negotiation is advantageous because the result shows there will be no more relocation. It means 
that the market is still allowed to operate on Notonegoro Street. For the organizer, the negotiation is advantageous because the result is not just the cancellation of relocation, but also location expansion to area in East Ring Road. However, according to the sellers, the expansion of market location is the form of loss in negotiation because it increases number of sellers. It means the business competition is getting tighter. In addition, this location expansion will impact on the integration of Sunmor UGM market with Sunmor Padukuhan Karangmalang market in East Ring Road. Such condition can reduce income since the larger number of sellers is not compensated with the increase of visitors.

The arrangement of location by sellers can reduce income. After an agreement has been signed with UGM concerning the location of market in Notonegoro Street and East Ring Road, market organizer intends to rearrange the market location in order to be more orderly and tidier. Such arrangement cannot be done by moving and evicting the sellers haphazardly. For that reason and to be fair, the arrangement conducted a lottery system. The sellers who get strategic location will feel happy because they are sure that despite the location movement, many or more visitors will come. Otherwise, those who get less strategic location will feel sad. But all of them state that this location arrangement lowers their income because they lose their customers. It is confirmed by Tia, a hijab seller, stating that "when I moved to this new location, I lost many customers. Perhaps my customers think that I was longer trade or they look for my new location lazily. Of course, it lowers my income".

These three strategies that decreased income of sellers seem to be in line with Ayuningsasi's (2011) study. The study analyzed the sellers' income before and after traditional market revitalization program in Denpasar City and resulted in three factors leading to the decrease of sellers' income: location change due to rearrangement, classification of sellers by similar products in the same location, and closeness of distance between revitalized market and other traditional markets.

The strategies which are not directly impacting sellers' fluctuating income are: regulation development, cooperation with security officer, cleanliness personnel provision, and market legal-entity establishment. Nevertheless, the strategy is important. It is necessary to maintain tidiness, discipline, orderliness, cleanliness, and sustainability to make the market operating well. It means that the sellers will remain to benefit from trading in Sunmor UGM market, although their income do not increase like that in previous location.

\section{Conclusion}

The development of strategy in managing Sunmor UGM market starts with observation on market environment by analyzing its strength, weakness, opportunity, and threat. Thereafter, the strategy is formulated and specified. There are nine strategies specified: developing regulation related to market management, arranging the location of sellers, registering incidental sellers to prevent the rise of illegal sellers, promoting the presence of market and various merchandise sold through social media, providing cleanliness personnel, expanding the parking lot for visitors, negotiating with UGM about the location of market, cooperating with security officer, and establishing legalentity market.

Out of nine strategies specified, only two strategies can impact on the increase of sellers' income: promotion through social media and parking lot provision. Meanwhile, three other strategies: incidental seller registration, location arrangement, and negotiation with UGM impact on the decrease of sellers' income. The rests strategies of regulation development, cooperation with security officer, cleanliness personnel provision, and legal-entity market establishment do not impact on sellers' fluctuating income.

\section{References}

Ayuningsasi, A. A. (2011). Analisis Pendapatan Pedagang Sebelum dan Sesudah Program Revitalisasi Pasar Tradisional di Kota Denpasar (Studi Kasus Pasar Sudha Merta Desa Sidakarya). Piramida, Vol. 7, No. 1, pp. $1-12$.

Belshaw, C. (1981). Tukar-Menukar di Pasar Tradisional dan Pasar Modern. Jakarta: Gramedia.

Binsar. (2017). Partisipasi Pedagang dalam Menjaga Ketertiban Pasar Kaget Minggu di Desa Tarai Bangun Kecamatan Tambang Kabupaten Tampar. JOM Fisip, Vol. 4, No. 1, pp. 1-14.

Fitriyani. (2017). Faktor-Faktor Penentu Keberhasilan Usaha di Kalangan Pedagang 
Sunday Morning UGM Yogyakarta. UIN Sunan Kalijaga.

Hunger, D., \& Wheelen, T. (2003). Manajemen Stratejik. Yogyakarta: Andi Offset.

Kristiyanti, M. (2012). Peran Strategis Usaha Kecil Menengah (UKM) dalam Pembangunan Nasional. Majalah Ilmiah Informatika, Vol. 3, No. 1, pp. 63-89.

Kurniawan, A., \& Yun, Y. (2018). Relationship Between Business Competence and Business Survival of Culinary Business in Bandung. Mimbar: Jurnal Sosial dan Pembangunan, Vol. 34, No. 1, pp. 147157.

Loso. (2010). Strategi Pengelolaan Pasar Tiban: Study Kasus di Kota Pekalongan. Jurnal IImu Pengetahuan dan Teknologi, Vol. 1, pp. 1-12.

Miles, H. B., \& Huberman, A. M. (1984). Qualitative Data Analyse, a Source Book of New Methods. Beverly Hill: Sage Publication.

Muslim, A. (2014). Model Pemberdayaan Ekonomi Masyarakat Miskin Perkotaan Berbasis Tanggung Jawab Sosial Masjid. UNS.
Rosyad, U. N. (2011). Pengaruh Komunikasi Pemasaran Terhadap Perluasan Pangsa Pasar. Mimbar: Jurnal Sosial dan Pembangunan, Vol. 27, No. 2, pp. 213224.

Siagian, S. P. (1995). Manajemen Stratejik. Jakarta: Bumi Aksara.

Simamora, B. (2011). Memenangkan Pasar dengan Pemasaran Efektif dan Profitabel. Jakarta: Gramedia.

Sudaryanto, Ragimun, \& Wijayanti, R. R. (2013). Strategi Pemberdayaan UMKM Menghadapi Pasar Bebas Asean. Jurnal Keuangan dan Moneter, Vol. 16, No. 1, pp. 1-32.

Widyasari, F. A., \& Yuniningsih, T. (2016). Analisis Strategi Pengelolaan Pasar Tradisional Bangsri di Dinas Koperasi, UMKM dan Pengelolaan Pasar Kabupaten Jepara. Journal of Public Policy and Management Review, Vol. 5, No. 2, pp. 321-333.

Winarni, S. (2006). Strategi Pengembangan Usaha Kecil Melalui Peningkatan Aksesibilitas Kredit Perbankan. Infokop, Vol. 22, No. 29. 